\title{
The Relation between Violence against Older Adult Women, their Quality of Life and Health Consequences
}

\author{
Soad Hassan Abd Elhameed, Lecturer \\ Gerontological Nursing, Faculty of Nursing, Mansoura University
}

\begin{abstract}
Violence against older adult women is a serious public health and human rights concern. It occurs in one or more of the following ways: physical, sexual, emotional, and financial violence. Moreover, it can have a myriad of devastating consequences on health and wellbeing of the older adult women. Along with the immediate physical and emotional impacts of violence, older adult women's overall quality of life adversely affected, which can in turn, influence their participation and engagement in various aspects of life and society. Objective: Determine the relation between violence against older adult women, their quality of life and health consequences. Settings: The inpatient units and geriatric outpatient clinics of Mansoura University Medical Hospital, Mansoura University Main Hospital and Mansoura General and New General Hospital affiliated to the Ministry of Health. Subjects: The study was carried out on 294 older adult women aged 60 year and above. Tools: Data was collected using four tools, tool I (Older adult women's socio-demographic \& clinical data structured interview schedule), tool II (Violence assessment structured interview schedule), tool III (Health consequences of violence against older adult women structured interview schedule) and tool IV (WHOQOL-BREF). Results: Nearly a quarter (23.8\%) of the study older adult women suffered from violence. Psychological and economic violence were the most common types of violence reported by the study older adult women. A statistically significant relationship was found between violence and quality of life. Conclusion: Violence consequences on psychological health were reported by the majority of the study violated older adult women. The violated women reported poor QOL, while non-violated women reported good QOL with a statistically significant difference between the violated and non violated older adult women. Recommendations: Responsible senior nurses in the inpatient units and the outpatient clinics prepare posters illustrating methods of avoidance of and protection from violence for older adult women. Messages about violence against older adult women and methods of prevention and protection from violence should be delivered to the older adult women via mass media to raise awareness.
\end{abstract}

Keywords: Violence, older adult women, quality of life.

\section{Introduction}

The older adult population has been increasing rapidly, with the most vulnerable groups of older people increasing at the fastest rate $^{(1)}$ and older adult women are among the fastest growing segment ${ }^{(2,3)}$. This dramatic increase has resulted in bringing concerns of elder violence to the fore ${ }^{(4)}$. As life expectancy increases, the older adult women will be subject to the same longterm, largely incurable and often disabling diseases associated with old age. The ageing process also exacerbates the impact that violence has on the health of the older women and chronic diseases of old age. The older adult women are physically weaker, more vulnerable than younger, they have a decreased reserve, their bones are more brittle and convalescence takes longer. Even a relatively minor injury can cause serious and permanent damage leading to loss of independence and mobility problems. They may be isolated, lonely or troubled by 
chronic illness as osteoarthritis in which case they are more vulnerable as targets for fraudulent schemes. Moreover, many older adult women survive on limited incomes and experience multiple losses ${ }^{(5,6)}$. All of which have tended to make the older adult poorer and more vulnerable.

The issue of violence against women has become a universal case due to its human, social and health dimensions. It is a multidimensional, multi-objective and multi-consequence case $^{(7)}$. The United Nations defines violence against women as "any act of gender-based violence that results in, or is likely to result in, physical, sexual or mental harm or suffering to women, including threats of such acts, coercion or arbitrary deprivation of liberty, whether occurring in public or in private life" ${ }^{(8)}$. Violence against the older adult women may occurs in one or more of the following ways: physical, sexual, emotional, and financial violence ${ }^{(9,10)}$. Physical violence refers to actions carried out with the intention of causing physical pain or injury to older person (e.g. being pushed, grabbed, slapped, hit, or hit by a thrown object). Psychological violence describes all actions inflicting mental pain, anguish or distress on a person through verbal or nonverbal acts (e.g. use of abusive language, oppression, manipulation, bullying, shouting, threats, humiliation, isolation of the older person). While, sexual violence refers to non-consensual sexual contact of any kind (e.g. unwanted intimacy, touching in a sexual way, rape, sexually slanted approaches). Financial or economic violence describes all actions of illegal or improper use of an elder's funds, property or assets (e.g. problems with powers of attorney, swindling, disappearance of money or goods, obstruction in managing one's own money, legacy hunting, and extortion) ${ }^{(1,11)}$.

The prevalence of it differed by sampling criterion, including whether old age was defined as beginning at 50 years, 60 years or 65 years $^{(12)}$. The rates of violence vary from $0.8 \%$ to $29.3 \%$ across Europe and overall $28.1 \%$ of older women had experienced some kind of violence or abuse $^{(11)}$. A WHO multi-country study found that between $15-71 \%$ of women reported experiencing physical and/or sexual violence by an intimate partner at some point in their lives ${ }^{(12)}$. Moreover, Samah et al (2009) ${ }^{(13)}$ illustrated that $50 \%$ of married, widowed and divorced women have subjected to some form of physical violence since the age of fifteen. The Social Gerontology framework assumes a broad array of potential perpetrators of mistreatment. These include spouse/ partner, adult children, grandchildren and other family relatives, neighbors and friends, and formal and informal caregivers $^{(14)}$. Violence may be a result of the interplay of several factors, including stress, the relationship between the carer and the care recipient, the existence of disruptive behavior and aggression by the care recipient, and depression in the caregiver. Living arrangements, particularly overcrowded conditions and a lack of privacy, loss of friends and family members reduces the opportunities for social interaction and cognitive and physical impairments ${ }^{(15-17)}$. In addition, social status, norms, employment and the tradition of the society are considered as risk factors to violence $^{(18)}$

The QOL literature in the field of ageing also overlaps with concepts such as successful, active and healthy ageing. In general, quality of life (QOL) is the perceived quality of an individual's daily life, that is, an assessment of their wellbeing or lack thereof. In health care, healthrelated quality of life is an assessment of how the individual's well-being may be affected over time by a disease, disability, or disorder ${ }^{(19)}$. All forms of violence can have damaging effects on women's physical health, emotional health, sexual health, spiritual health and financial well-being. It can lead to poor physical and mental health, depression, Loss of will to live and/or Suicide ${ }^{(20)}$. In addition, women's overall 
quality of life can adversely affected by violence, which can, in turn, influence their participation and engagement in various aspects of life and society. These consequences to the older adult women, along with the violent act itself, can have ruffle effects on society as a whole ${ }^{(21)}$. Therefore, the impact of violence against older persons is considered a concern for all people in this province and preventing violence against older persons is everybody's responsibility ${ }^{(20)}$. The older women experiencing violence have essentially the same needs as younger women, e.g. safety, security, access to health care, social and familial ties, but may require services and support that are delivered in different ways than those designed for younger women.

Nursing is concerned with providing care (holistic care) to the older adults. Therefore, gerontological nurses must be vigilant and sensitive to the potential of violence and observing for the signs and symptoms of violence in all their interaction with vulnerable older adults ${ }^{(10,22,23)}$. In addition, violence assessment should be an integral part for all nurses either in inpatient units, outpatient clinics, emergency units, assisted living facilities, elderly clubs, family health centers and every encounter with older adult women. Violence later in life often goes underreported or unrecognized so nurses must be aware of the resources and interventions specific to serving the unique needs of the older adults women. Moreover, nurses and other health care professionals have responded to the problem of violence by engaging in increasingly specific researches, designing prevention and intervention programs, and advocating for social change to meet needs of those older adult women.

\section{Aim of the Study}

To determine the relation between violence against older adult women, their quality of life and health consequences.

\section{Research Question:}

What is the relation between violence against older adult women, their quality of life and health consequences?

\section{Materials and Method}

\section{Materials}

Design: A descriptive co relational design was followed.

Settings: The study was carried out in four areas, first inpatient medical units of Mansoura Main University Hospital, second the inpatient medical units of Mansoura New General Hospital, third the geriatric outpatient clinics of Mansoura General Hospital and fourth the geriatric outpatient clinic of Mansoura University Medical Hospital.

Subjects: The study included 294 older adult women aged 60 year and above, attended the previous study settings and able to communicate.

Tools: The following tools were used for data collection:

Tool I: Older adult women's sociodemographic \& clinical data structured interview schedule

This tool was developed by the researcher based on relevant literature review. It included socio-demographic data such as age, marital status, level of education, current occupation, residence, income $\&$ its source, living condition, presence of disease and the medication taken, occurrence of violence and the perpetrator.

\section{Tool II: Violence assessment structured} interview schedule

This tool was developed by the researcher based on relevant literature review $^{(2,24,25)}$ to assess violence against women. It consists of 30 questions related to economic violence, physical violence, psychological violence and sexual violence. The responses to questions were scored on a 
3 point Likert scale, a response of never done takes a score of zero (0), sometimes done takes a score of one (1) and always done takes a score of two (2). The total score is 60 (10 for economic violence, 20 for physical violence, 20 for psychological violence and 10 for sexual violence). The higher score indicates a greater level of violence against the older adult women.

Tool III: Health consequences of violence against older adult women structured interview schedule

This tool was developed by the researcher based on review of relevant literature $^{(2,24,25)}$ to assess the consequences of violence on older adult women health status. It consists of 10 questions related to womens' physical health status and 13 to psychological health status. Responses to each of the questions are with either yes or no, where No takes a score of zero (0) and Yes takes a score of one (1). The total score was computed out of 23 . The higher score indicates a negative impact of violence on women health status (negative health consequences).

\section{Tool IV: WHO Quality of life-bref (WHOQOL-BREF)}

The World Health Organization Quality of Life-Bref (WHOQOL-BREF) instrument was developed in $1997^{(26)}$ and was updated in 2014, and translated into Arabic and tested for its validity and reliability by Ahmed $(2008)^{(27)}$. The reliability was assured by Spearman's correlation coefficient $r=0.884$. It is used to assess the individual's perceptions in the context of their culture and value systems, and their personal goals, standards and concerns. The WHOQOL-Bref produces a profile with four domain scores (physical health, psychological, social relationships and environment) and two individually scored items about an individual's overall perception of quality of life and health. It contains 26 questions. Scoring of the items is made using a 5-point likert scale ranging from one (1) to five (5). The four domain scores are scaled in a positive direction with higher scores indicating a higher quality of life.

\section{Method}

1- Official letters were issued to the directors of the Mansoura Main University Hospital, Mansoura New General Hospital, Mansoura General Hospital and Mansoura University Medical Hospital, to obtain their approval in order to collect the necessary data.

2- Study tools I (Older adult women's socio-demographic \& clinical data structured interview schedule), tool II (Violence assessment structured interview schedule) and tool III (Health consequences of violence against older adult women structured interview schedule) were developed by the researcher after reviewing the relevant literature.

3- The Arabic version of the study tool IV (WHOQOL-BREF) was used.

4- Study tools I, II, III were tested for content validity by a jury of five experts in the related fields of the study (gerontological nursing, community health nursing, medical surgical nursing and biostatistics). The necessary modifications were carried out accordingly.

5- A pilot study was carried out on 10 of older adult women at Mansoura University Medical Hospital geriatric outpatient clinic to ascertain the clarity and applicability of the study tools, also to estimate the approximate time needed to complete the study tools. In light of the findings of the pilot study, the necessary modifications were done. Then, the tools were put into their final form. Those were not included in the study.

6- According to the schedule designed by the researcher, each older adult women was interviewed individually 
by the researcher after introducing herself and the purpose of the study to collect the necessary data using the study tools.

7- The researcher started data collection according to a schedule, three days a week namely; Saturday, Sunday and Monday. The schedule start from 10 am to $12 \mathrm{pm}$ within a period of three months. The interview time of each older adult woman ranged from 20-30 minute.

8- Data collection started from the first of March 2013 to the end of May 2013.

\section{Ethical considerations:}

Verbal consent was obtained from the study older adult women after explanation of the purpose of the study. Each older adult woman was assured about the confidentiality and anonymity of the collected data. The privacy of each older adult woman was maintained and their right to withdraw from the study any time without penalties.

\section{Statistical Analysis}

Data were analyzed using the Statistical Package of Social Science (SPSS) software version 16.0. The 0.05 level was used as the cut off value for statistical significance and the following statistical measures were used: descriptive statistics (count \& percentage, minimum-maximum, mean \&standard deviation) and analytical statistics (Pearson's chi square test, Monte Carlo Exact test and Independent sample ttest).

\section{Study limitation:}

A large number of older adult women attending the study settings refused to participate in the study. They constituted 66 older adult women.

\section{Results}

Table (1) shows that $62.9 \%$ of the study older adult women were less than 65 years old. Those 75 years and more constituted $21.4 \%$. The mean age is $65.31 \pm 6.82$ year. More than half $(58.2 \%)$ live in urban area, $59.2 \%$ are widows and $35 \%$ are still married. Illiteracy is prevalent among $66.0 \%$ of the study older adult women and $85.7 \%$ are housewives. Moreover, $60.5 \%$ reported having enough income, for $65.0 \%$ pension was the main source of income and $72.8 \%$ live with their families.

Table (2) shows that more than two third $(71.1 \%)$ suffer from chronic diseases. Cardiovascular disease and diabetes mellitus were the more frequently reported diseases among the studied older adult women $(71.8 \%$ and $54.1 \%$ respectively) and antihypertensive and hypoglycemic drugs were reported by $71.8 \%$ and $54.1 \%$ respectively. This is because these two drugs are the only medications dispensed from the hospital.

Figure (1) shows that nearly a quarter $(23.8 \%)$ of the study older adult women were exposed to violence and $76.2 \%$ were not.

Figure (2) shows that, the main reported perpetrator was the siblings $(57.1 \%)$ followed by $20 \%$ the husband, $12.9 \%$ from the daughter in law and only $10 \%$ report violence from relatives.

Table (3) shows that, the most common type of violence reported was psychological violence $(95.7 \%)$ followed by economic violence $(78.6 \%)$, physical violence $(60 \%)$ and only $18.6 \%$ sexual violence.

Table (4) shows the health consequences reported by the violated older adult women. It appears from the table that, 92.9\% reported suffering from psychological health problems as nervousness, restlessness, desire to commit suicide and anxiety. While, physical health problems as bruises, fractures, deformity, pain in the body and inability to perform 
usual activities were reported by $76.1 \%$. The mean total score for psychological and physical health problems related to violence are $6.14 \pm 3.14$ and $3.19 \pm 2.18$ respectively.

Table (5) comparing the perception of health and quality of life (QOL) among the violated and non-violated older adult women. The table shows that among the violated older adult women $30 \%$ and $17.1 \%$ rated their QOL as very poor and poor respectively compared to only $4(1.7 \%)$ among the non-violated group. None of the violated older adult women rated their QOL as very good and only $9(12.9 \%)$ rated it as good compared to $17.0 \%$ and $31.3 \%$ among the non-violated group. The difference are statistically significant $(\mathrm{P}=0.000)$ and $(\mathrm{P}=0.000)$ respectively for $\mathrm{QOL}$ and satisfaction with own health.

Table (6) shows that violated older adult women have a lower total mean score in all QOL domains. While, a high mean total score was found among non-violated older adult women in all QOL domains. The difference between the two groups is statistically significant for all QOL domains $(\mathrm{P}=0.000)$.

Table (7) shows the relationship between socio-demographic characteristics, presence of disease and presence of violence against older adult women. A statistically significant difference was observed between violated and non-violated older adult women as regards place of residence $(\mathrm{P}=0.000)$, marital status $(\mathrm{P}=$ $0.002)$, level of education $(\mathrm{P}=0.000)$ and income $(\mathrm{P}=0.001)$.

\section{Discussion}

Violence against older adult women can be part of an ongoing phenomenontaking place within marriage or family for many years. Long-term violence and abuse can take its toll on older women who may suffer from health problems over their chronological years and affect their capacity to cope with everyday life. Moreover, violence against older adult women is also likely to co-exist with society's prejudice against older people, rendering older women's suffering and needs invisible. ${ }^{(16)}$ Reports of older adult violence are increasing, and it is now recognized as a major social and health problem and a significant aspect of family violence ${ }^{(1)}$. Therefore the present study was conducted in order to determine the relation between violence against older adult women, their quality of life and health consequences. The study result revealed that nearly a quarter of the study older adult women suffered from violence (figure 1). This result is congruent with those of Luoma et al (2011) $)^{(11)}$ who reported that violence are ranged from $21.8 \%$ to $39.4 \%$ among older adult women in different countries.

With respect to age, more than half of violated older adult women were young old (60-65years) (table 1). This finding supports that of Fisher et al (2011) $)^{(12)}$ who reported that a high percent of violence was observed among women aged 60-64 years. Becoming an old person with the physiological, psychological and social changes they face make them a vulnerable group for violence. Also, the young old women constituted the high percentage of the study sample and this may reflect the high percentage of violence among them. In addition, more than half of the older adult women who reported violence live in rural area (table 1). This result is in line with the result of Morsy et al (2013) ${ }^{(28)}$. Moreover, the Central Agency for Public Mobilization and Statistics Egypt (2009) ${ }^{(29)}$ documented that rural women were more likely than urban women to report a recent episode of violence.

Violated women were observed more among married and widows (table 7). The married women were exposed to violence from their husband and the widow violence may be related to multiple losses facing them. The housewives and illiteracy were prevailing among more than half of older adult women who suffered from violence. Improving the access to education for 
women and raising education levels in the whole society may help reducing women violence. Moreover, the present study revealed also that these women do not have enough money to live and buy their needs (table 7). This is because the older adult women traditionally face a greater risk of ending up living in poverty as a result of lower pension and income. Therefore, older adult women have a greater need for health services. The lack of financial resources has significant effect on their physical and mental health, their ability to take preventive measures, to buy aids to compensate for deteriorating faculties, and ultimately to participate in community life and this will lead to being at risk for violence. In addition, early intervention to educate women is essential because "maintaining control of their daily financial matters" will enable them to age successfully. Nearly two thirds of the violated older adult women still live with their families. This reflects the concept of extended family especially in the rural communities to care for the older adult and to maintain social and family relations. In addition, most of violence occurs in the home setting, where the majority of Caregiving occurs. This result is in accordance with the result of Luoma et al $(2011)^{(11)}$, Ramadan $(2007)^{(7)}$ and Samah et al $(2009)^{(13)}$.

Moreover, more than three quarters of violated older adult women suffered from chronic diseases. This result may be related to increasing prevalence of chronic diseases with old age, which is considered a risk factor for violence. Because they have tendency to a decrease in body organ physiological reserve additional to environmental and psychosocial stressors. Therefore, it is important to support a life course approach, which recognizes that health promotion and disease prevention need to focus on maintaining independence, prevention and delay of disease and disability in order to eliminate the risk of violence. A statistically significant relation was found between violated and non- violated older adult women in relation to residence, marital status, level of education and income (table 7). This in accordance with a study done in Egypt by Morsy et al $(2013)^{(28)}$.

The study revealed that, the perpetrator was mainly the siblings and husband (figure 2). This may be because widow women live with their siblings especially the eldest son after death of her husband and this may increase the risk to be violated beside the other risk factors. Montero et al (2013) ${ }^{(31)}$ and Lazenbatt et al $(2013)^{(30)}$ reported that older adult women are violated by husband. While, Luma et al $(2011)^{(11)}$ reported that in most cases, perpetrator of emotional, financial, and sexual abuse were the women partner. As a result, it is important to teach family members about the aging process, problems and multiple losses they faced and engage them in the care of the older adult women. This will help in increase family awareness and help in decreasing older adult women exposure to violence. In addition, it is important to highlight the need for healthcare professionals to receive an appropriate training, knowledge and skills necessary to confront the reality of this situation to support the older women who suffer this type of violence effectively.

Violence is a profound health problem that saps women's energy, compromises their physical and mental health, and erodes their self-esteem ${ }^{(32)}$. On examining types of violence against violated older adult women, the present study revealed that psychological violence is the most common type of violence followed by economic violence, physical violence and sexual violence respectively (table 3 ). This result is in accordance with the study of $\mathrm{Wu}$ et al $(2012)^{(33)}$ which was carried out among community-dwelling older adults aged 60 years and living in a rural community that psychological violence was the highest prevalent form of violence against older adult women. Moreover, Cook $\mathrm{J}$ et al $(2011)^{(2)}$ recorded that, women over 55 years reported less lifetime exposure to 
physical and sexual assaults. While, Ogrodnik $(2008)^{(34)}$ reported that, financial victimization is the most common form of violence that older persons are likely to face.

With regard to consequences of violence on the older adult women health status, the present study showed that, violence had a negative impact on both physical and psychological health status of violated women (table 4). Nevertheless, the majorities of the violated older adult women reported psychological health problems as panic attacks, acute anxiety, feeling of frustration, anger, helplessness, hopelessness, and low self-esteem. This result is consistent with the result of Lazenbatt et al (2010) ${ }^{(35)}$ and Mc Garry \& Simpson $(2011)^{(36)}$. They found that older battered women faced an increased risk of psychological problems. In addition, Hightower et al (2006) ${ }^{(37)}$ found that abuse of the older adult had a health impact in both physical and mental, including depression, fatigue, anxiety and confusion, irritable bowel syndrome and ulcers. Therefore, the gerontological nurse must understand the phenomenon of violence in its various aspects to help her in providing the appropriate psychological interventions to the violated older adult women.

Quality of life is a holistic approach that not only emphasizes on individuals' physical, psychological, and spiritual functioning but also their connections with their environments and opportunities for maintaining and enhancing skills. Ageing, along with the functional decline, economic dependence and social cut off, violence compromises the quality of life ${ }^{(38)}$. The current study showed that; the violated older adult women have a low perception on rating their QOL and low satisfaction with their health (table 5) as well as poor in all quality of life domains (table 6) rather than non violated older adult women. The difference between the two groups was statistically significant. In relation to violence in overall terms, the present study revealed that, older adult women have a high mean total score of social relationships followed by physical health, psychological and environment domain of QOL respectively. This is not in the same line of Wittenberg et al (2007) ${ }^{(39)}$ who reported that psychological health was the most severely affected domain. The older adult women who suffer from violence had a lower mean total score of quality of life than who do not and the difference was statistically significant (table 6). This is in accordance with the results of Luoma et al $(2011)^{(11)}$. Therefore, it is important to focus on improving quality of life of the violated older adult women in order to maintain their health and wellbeing as well as have a successful aging. Finally, we can say that violence against older adult women is an important neglected public health problem in the Egyptian community that needs multidisciplinary approach to understand its causes and plan an effective preventive measures as well as management of its consequences.

\section{Conclusion}

Based on the findings of the present study, it can be concluded that psychological violence is the most common type of violence reported by the violated older adult women. The majority of the violated older adult women reported negative consequences on their psychological and physical health status. With regard to the quality of life, the violated older adult women reported poor total mean score in their overall perception of health and QOL rather than non-violated older adult women.

\section{Recommendations}

1. Nurses in the inpatient units and the outpatient clinics should teach the older adult women methods of avoidance of and protection from violence using posters and booklets.

2. Messages about violence against older adult women and methods of prevention 
and protection from violence to be delivered to the older adult women via mass media to raise awareness.

3. Violence assessment should be an integral part of the overall nursing assessment of older adult women either in inpatient units or outpatients clinics.
4. The government should give a look to the health delivery system and economic status of the older adult women in order to meet their needs and improve their health status. 
Table (1): Socio-demographic characteristics of the study older adult women.

\begin{tabular}{|c|c|c|}
\hline Socio-demographic characteristics & $n=294$ & $\%$ \\
\hline $\begin{array}{l}\text { Age (in years): } \\
60- \\
65- \\
70- \\
75- \\
80+ \\
\end{array}$ & $\begin{array}{l}185 \\
34 \\
12 \\
53 \\
10 \\
\end{array}$ & $\begin{array}{c}62.9 \\
11.6 \\
4.1 \\
18.0 \\
3.4\end{array}$ \\
\hline Mean \pm SD & \multicolumn{2}{|c|}{$65.31 \pm 6.82$} \\
\hline $\begin{array}{l}\text { Residence } \\
\text { Urban } \\
\text { Rural }\end{array}$ & $\begin{array}{l}171 \\
123 \\
\end{array}$ & $\begin{array}{r}58.2 \\
41.8 \\
\end{array}$ \\
\hline $\begin{array}{l}\text { Marital status } \\
\text { Widow } \\
\text { Married } \\
\text { Single } \\
\text { Divorced } \\
\end{array}$ & $\begin{array}{c}174 \\
103 \\
10 \\
7 \\
\end{array}$ & $\begin{array}{c}59.2 \\
35.0 \\
3.4 \\
2.4 \\
\end{array}$ \\
\hline $\begin{array}{l}\text { Educational level } \\
\text { Illiterate } \\
\text { Read \&write } \\
\text { Secondary education } \\
\text { University education }\end{array}$ & $\begin{array}{l}194 \\
38 \\
47 \\
15\end{array}$ & $\begin{array}{c}66.0 \\
12.9 \\
16.0 \\
5.1\end{array}$ \\
\hline $\begin{array}{l}\text { Current occupation } \\
\text { Not working } \\
\text { Working }\end{array}$ & $\begin{array}{c}252 \\
42 \\
\end{array}$ & $\begin{array}{l}85.7 \\
14.3 \\
\end{array}$ \\
\hline $\begin{array}{l}\frac{\text { Income }}{\text { Enough }} \\
\text { Not enough } \\
\text { Enough and save }\end{array}$ & $\begin{array}{c}178 \\
87 \\
29 \\
\end{array}$ & $\begin{array}{c}60.5 \\
29.6 \\
9.9 \\
\end{array}$ \\
\hline $\begin{array}{l}\text { Income source \# } \\
\text { Pension } \\
\text { Work } \\
\text { Husband } \\
\text { Social support } \\
\text { Siblings help } \\
\text { Others }\end{array}$ & $\begin{array}{c}206 \\
42 \\
22 \\
16 \\
15 \\
8 \\
\end{array}$ & $\begin{array}{l}70.1 \\
14.3 \\
7.5 \\
5.4 \\
5.1 \\
2.7 \\
\end{array}$ \\
\hline $\begin{array}{l}\text { Living condition } \\
\text { Family home } \\
\text { Own home }\end{array}$ & $\begin{array}{c}214 \\
80\end{array}$ & $\begin{array}{l}72.8 \\
27.2\end{array}$ \\
\hline
\end{tabular}

\# Not mutually exclusive 
Table (2): Distribution of the study older adult women according to their medical history.

\begin{tabular}{||l|c|c|}
\hline \multicolumn{1}{|c|}{ Medical history } & $\mathbf{n = 2 9 4}$ & \% \\
\hline Presence of disease & 209 & 71.1 \\
\hline Yes & 85 & 28.9 \\
No & 150 & 71.8 \\
\hline Diseases (n= 209) $\#$ & & 54.1 \\
Cardiac & 113 & 15.3 \\
Diabetes mellitus & 32 & 15.3 \\
Renal & 32 & 8.1 \\
Rheumatic & 17 & 7.2 \\
Gastrointestinal & 15 & 3.3 \\
Respiratory & 7 & 2.4 \\
Parkinsonism & 5 & 71.8 \\
Others & 150 & 54.1 \\
\hline Medication \# & 113 & 11.9 \\
\hline Antihypertensives & 25 & \\
Hypoglycemics & & \\
Analgesics & \multicolumn{2}{|l}{} \\
\hline
\end{tabular}

\# Not mutually exclusive

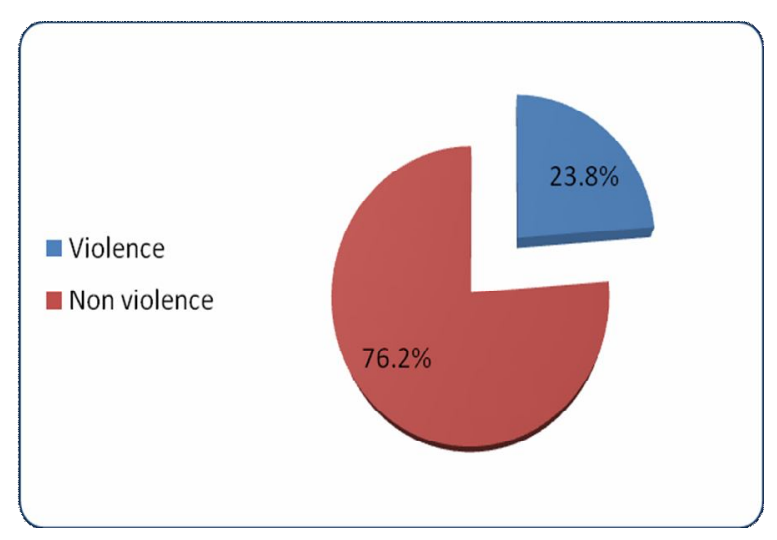

Figure (1): Distribution of the study older adult women according to presence of violence

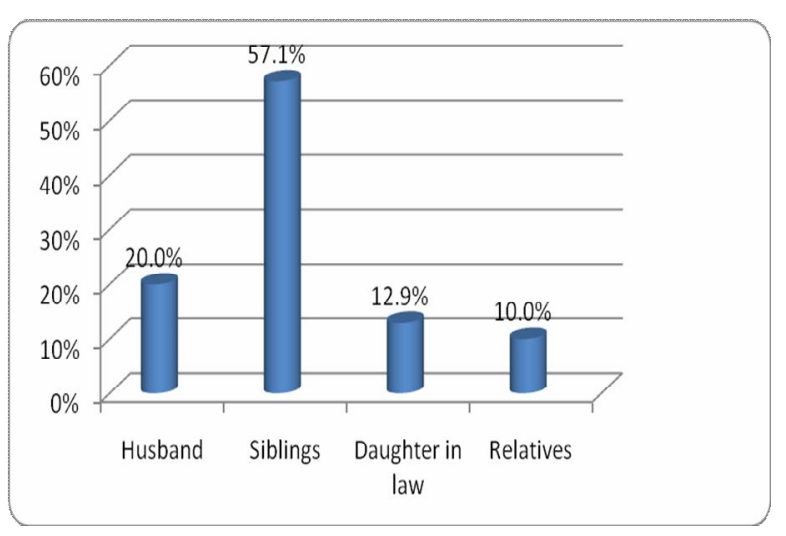

Figure (2): Distribution of the violated older adult women according to perpetrator

Table (3): Types of violence reported by the study violated older adult women.

\begin{tabular}{||l|c|c|c|c||}
\hline \multirow{2}{*}{\multicolumn{1}{|c|}{ Types of violence \# }} & \multirow{2}{*}{$\mathbf{n = 7 0}$} & \multirow{2}{*}{$\%$} & \multicolumn{2}{c|}{ Total mean score of violence } \\
\cline { 4 - 5 } & & & Min-Max & Mean \pm SD \\
\hline Psychological violence & 67 & 95.7 & $2-16$ & $7.09 \pm 4.12$ \\
\hline Economic violence & 55 & 78.6 & $1-9$ & $3.58 \pm 2.65$ \\
\hline Physical violence & 42 & 60.0 & $1-14$ & $3.81 \pm 2.45$ \\
\hline Sexual violence & 13 & 18.6 & $1-5$ & $2.84 \pm 1.28$ \\
\hline
\end{tabular}

\# Not mutually exclusive 
Table (4): Health consequences of violence reported by the study violated older adult women.

\begin{tabular}{|c|c|c|c|c|}
\hline \multirow[t]{2}{*}{ Health consequences of violence \# } & \multirow[t]{2}{*}{$n=70$} & \multirow[t]{2}{*}{$\%$} & \multicolumn{2}{|c|}{$\begin{array}{c}\text { Total mean score of } \\
\text { violence }\end{array}$} \\
\hline & & & Min-Max & Mean \pm SD \\
\hline $\begin{array}{l}\text { Violence consequences on psychological } \\
\text { health status (ex. nervous, restlessness, } \\
\text { desire to commit suicide, anxiety, etc....) }\end{array}$ & 65 & 92.9 & $2-11$ & $6.14 \pm 3.14$ \\
\hline $\begin{array}{l}\text { Violence consequences on physical } \\
\text { health status (ex. bruises, fractures, } \\
\text { deformity, pain in the body, etc.....) }\end{array}$ & 47 & 67.1 & $1-12$ & $3.19 \pm 2.18$ \\
\hline
\end{tabular}

\# Not mutually exclusive

Table (5): Relation between violence against older adult women and their overall perception of health and quality of life (QOL).

\begin{tabular}{|c|c|c|c|c|c|}
\hline \multirow{2}{*}{$\begin{array}{c}\text { Older adult women overall } \\
\text { perception of health and quality } \\
\text { of life }\end{array}$} & \multicolumn{2}{|c|}{$\begin{array}{l}\text { Violated older } \\
\text { adult women }\end{array}$} & \multicolumn{2}{|c|}{$\begin{array}{c}\text { Non-violated } \\
\text { older adult } \\
\text { women }\end{array}$} & \multirow[t]{2}{*}{$\begin{array}{l}\mathbf{X}^{2} \\
(\mathbf{P})\end{array}$} \\
\hline & $n=70$ & $\%$ & $n=224$ & $\%$ & \\
\hline $\begin{array}{l}\text { Satisfaction with own health } \\
\text { Very dissatisfied } \\
\text { Dissatisfied } \\
\text { Neither satisfied nor dissatisfied } \\
\text { Satisfied } \\
\text { Very satisfied }\end{array}$ & $\begin{array}{c}4 \\
13 \\
33 \\
18 \\
2 \\
\end{array}$ & $\begin{array}{c}5.7 \\
18.6 \\
47.1 \\
25.7 \\
2.9 \\
\end{array}$ & $\begin{array}{c}0 \\
6 \\
56 \\
125 \\
37 \\
\end{array}$ & $\begin{array}{c}0.0 \\
2.7 \\
25.0 \\
55.8 \\
16.5 \\
\end{array}$ & $\begin{array}{c}59.713 \\
(0.000) * \wedge\end{array}$ \\
\hline $\begin{array}{l}\text { Rating own QOL } \\
\text { Very poor } \\
\text { Poor } \\
\text { Neither poor nor good } \\
\text { Good } \\
\text { Very good }\end{array}$ & $\begin{array}{c}21 \\
12 \\
28 \\
9 \\
0\end{array}$ & $\begin{array}{c}30.0 \\
17.1 \\
40.0 \\
12.9 \\
0.0\end{array}$ & $\begin{array}{c}1 \\
3 \\
112 \\
70 \\
38\end{array}$ & $\begin{array}{c}0.4 \\
1.3 \\
50.0 \\
31.3 \\
17.0\end{array}$ & $\begin{array}{c}1.081 \\
(0.000)^{* \wedge}\end{array}$ \\
\hline
\end{tabular}

*Significant at $\mathrm{p} \leq 0.05$

$\wedge \mathrm{P}$ value based on Monte Carlo exact probability

Table (6): Relation between quality of life domains and the presence of violence against older adult women.

\begin{tabular}{||l|c|c|c||}
\hline \multicolumn{1}{|c|}{$\begin{array}{c}\text { Quality of life } \\
\text { domains }\end{array}$} & $\begin{array}{c}\text { Violated older } \\
\text { adult women } \\
(\mathbf{n = 7 0 )}\end{array}$ & $\begin{array}{c}\text { Non-violated older } \\
\text { adult women } \\
(\mathbf{n = 2 2 4})\end{array}$ & \multirow{2}{*}{$\begin{array}{c}\text { t-test } \\
(\mathbf{P})\end{array}$} \\
\cline { 2 - 3 } & Mean \pm SD & Mean \pm SD & \\
\hline Social relationships & $46.37 \pm 20.89$ & $61.37 \pm 16.97$ & $6.092(0.000)^{*}$ \\
\hline Physical health & $40.59 \pm 17.94$ & $57.01 \pm 17.89$ & $6.705(0.000)^{*}$ \\
\hline Psychological & $37.67 \pm 16.57$ & $58.29 \pm 18.32$ & $8.401(0.000)^{*}$ \\
\hline Environment & $37.59 \pm 18.85$ & $61.73 \pm 18.77$ & $9.385(0.000)^{*}$ \\
\hline
\end{tabular}

*Significant at $\mathrm{p} \leq 0.05$ 
Table (7): Relation between socio-demographic characteristics, presence of chronic disease and presence of violence against older adult women.

\begin{tabular}{|c|c|c|c|c|c|}
\hline \multirow{2}{*}{$\begin{array}{l}\text { Socio-demographic } \\
\text { characteristics }\end{array}$} & \multicolumn{2}{|c|}{$\begin{array}{l}\text { Violated older } \\
\text { adult women }\end{array}$} & \multicolumn{2}{|c|}{$\begin{array}{l}\text { Non violated older } \\
\text { adult women }\end{array}$} & \multirow{2}{*}{$\begin{array}{l}\mathbf{X}^{2} \\
(\mathbf{P})\end{array}$} \\
\hline & $\mathrm{n}=\mathbf{7 0}$ & $\%$ & $\mathrm{n}=224$ & $\%$ & \\
\hline $\begin{array}{l}\text { Age (in years): } \\
60- \\
65- \\
70- \\
75- \\
80+\end{array}$ & $\begin{array}{c}38 \\
10 \\
3 \\
17 \\
2 \\
\end{array}$ & $\begin{array}{c}54.3 \\
14.3 \\
4.2 \\
24.3 \\
2.9 \\
\end{array}$ & $\begin{array}{c}147 \\
24 \\
9 \\
36 \\
8 \\
\end{array}$ & $\begin{array}{c}65.6 \\
10.7 \\
4.0 \\
16.1 \\
3.6 \\
\end{array}$ & $\begin{array}{c}3.764 \\
(0.447)\end{array}$ \\
\hline $\begin{array}{l}\text { Residence } \\
\text { Urban } \\
\text { Rural }\end{array}$ & $\begin{array}{l}28 \\
42 \\
\end{array}$ & $\begin{array}{l}40.0 \\
60.0\end{array}$ & $\begin{array}{c}143 \\
81\end{array}$ & $\begin{array}{l}63.8 \\
36.2 \\
\end{array}$ & $\begin{array}{c}12.456 \\
(0.000)^{*}\end{array}$ \\
\hline $\begin{array}{l}\text { Marital status } \\
\text { Widow } \\
\text { Married } \\
\text { Single } \\
\text { Divorced } \\
\end{array}$ & $\begin{array}{c}30 \\
31 \\
4 \\
5\end{array}$ & $\begin{array}{c}42.9 \\
44.3 \\
5.7 \\
7.1 \\
\end{array}$ & $\begin{array}{c}144 \\
72 \\
6 \\
2 \\
\end{array}$ & $\begin{array}{c}64.3 \\
32.1 \\
2.7 \\
0.9 \\
\end{array}$ & $\begin{array}{c}16.578 \\
(0.002)^{* \wedge}\end{array}$ \\
\hline $\begin{array}{l}\text { Educational level } \\
\text { Illiterate } \\
\text { Read \&write } \\
\text { Secondary education } \\
\text { University education }\end{array}$ & $\begin{array}{c}41 \\
19 \\
10 \\
0 \\
\end{array}$ & $\begin{array}{c}58.6 \\
27.1 \\
14.3 \\
0.0 \\
\end{array}$ & $\begin{array}{c}153 \\
19 \\
37 \\
15\end{array}$ & $\begin{array}{c}68.3 \\
8.5 \\
16.5 \\
6.7 \\
\end{array}$ & $\begin{array}{c}19.988 \\
(0.000)^{* \wedge}\end{array}$ \\
\hline $\begin{array}{l}\text { Current occupation } \\
\text { Not working } \\
\text { Working }\end{array}$ & $\begin{array}{c}59 \\
8\end{array}$ & $\begin{array}{l}84.3 \\
11.4 \\
\end{array}$ & $\begin{array}{c}193 \\
34\end{array}$ & $\begin{array}{l}86.2 \\
15.2 \\
\end{array}$ & $\begin{array}{l}0.179 \\
(0.95) \\
\end{array}$ \\
\hline $\begin{array}{l}\text { Income } \\
\text { Enough } \\
\text { Not enough } \\
\text { Enough and save }\end{array}$ & $\begin{array}{l}28 \\
32 \\
10 \\
\end{array}$ & $\begin{array}{l}40.0 \\
45.7 \\
14.3 \\
\end{array}$ & $\begin{array}{l}150 \\
55 \\
19 \\
\end{array}$ & $\begin{array}{l}67.0 \\
24.5 \\
8.5 \\
\end{array}$ & $\begin{array}{c}16.296 \\
(0.001)^{* \wedge}\end{array}$ \\
\hline $\begin{array}{l}\text { Living condition } \\
\text { Family home } \\
\text { Own home }\end{array}$ & $\begin{array}{l}46 \\
24 \\
\end{array}$ & $\begin{array}{l}65.7 \\
34.3 \\
\end{array}$ & $\begin{array}{c}168 \\
56\end{array}$ & $\begin{array}{l}75.0 \\
25.0 \\
\end{array}$ & $\begin{array}{c}2.322 \\
(0.128)\end{array}$ \\
\hline $\begin{array}{l}\text { Presence of disease } \\
\text { Yes } \\
\text { No }\end{array}$ & $\begin{array}{l}54 \\
16\end{array}$ & $\begin{array}{l}77.1 \\
22.9\end{array}$ & $\begin{array}{c}155 \\
69 \\
\end{array}$ & $\begin{array}{l}69.2 \\
30.8\end{array}$ & $\begin{array}{c}1.639 \\
(0.201)\end{array}$ \\
\hline
\end{tabular}

*Significant at $\mathrm{p} \leq 0.05$

$\wedge \mathrm{P}$ value based on Monte Carlo exact probability 


\section{References}

1. Miller C. Nursing for wellness in older adults. $6^{\text {th }}$ ed., Philadelphia: Lippincott Williams \& Wilkins, 2012: 162-183.

2. Cook J, Dinnen S, and O'Donnell C. Older women survivors of physical and sexual violence: A systematic review of the quantitative literature. Journal of women's health 2011; 20(7): 1075-1081. Retrieved on December 2012. Available at: http://www.ncbi.nlm.nih.gov.

3. Abd Elhameed S. Relation between nursing students' knowledge of aging and attitude towards older adult people and their will and intent to work with the older adult. Journal of education and practice 2013; 4(27): 125-136. Retrieved on June 2013. Available at: http://www.iiste.org.

4. De Donder L, Luoma M, Penhale B, Lang G, Santos A, Tamutiene I, Koivusilta M, Schopf A, Alves J, Reingarde J, Perttu S, Savola T and Verté D. European map of prevalence rates of elder abuse and its impact for future research. European Journal of Ageing 2011; 8(2): 129-143. Retrieved on October 15, 2012. Available at: http://www.link.springer.com.

5. World Health Organization. Violence and injury prevention: Global status report on violence prevention. 2014. Chapter 5: 125-142. Abuse of the older adult. Retrieved on November 2014. Available at: http://www.who.int/violence_injury.

6. National Center on Older adult Abuse. Administration on aging: Statistics/Data. 2014. Retrieved on September 2014. Available at: http://www.ncea.aoa.gov.

7. Ramadan H. Types of violence against woman in rural societies: A sociological study in one of the Dakahlia Governorate villages. Master Thesis, Faculty of Arts: Mansoura University, Egypt; 2007. Retrieved on December 30,
2012.

Available

at:

http://srv5.eulc.edu.eg.

8. World Health Organization. Violence against women. 2010. Retrieved on July 2012. Available at: http://www.who.in/countries/en.

9. Domestic Violence and Sexual Assault Council. Domestic violence against older women. 2011. Retrieved on November 2012. Available at: http://www.dvsac.org.

10. Touhy T and Jett K. Ebersole and Hess' Gerontological nursing and health aging. $3^{\text {rd }}$ ed., St. Louis: Mosby Inc., 2010; 364367.

11. Luoma M, Koivusilta M, Lang G, Enzenhofer E, Donder L, Verte D, Reingarde J, Tamutiene I, Alves J, Santos A and Penhale B. Prevalence study of abuse and violence against older women. Results of a multi-cultural survey in Australia, Belgium, Finland, Lithuania, and Portugal (European report of the AVOW project). Finland: National institute for health and welfare. 2011. Retrieved on September 2012. Available at: http://www.thl.fi/avow.

12. Fisher S, Zink T, and Regan L. Abuses against older women: Prevalence and health effects. Journal of Interpersonal Violence 2011; 26(2): 254-268. Retrieved on May 2014. Available at: http://www.ncbi.nlm.nih.gov.

13. Samah S, Zaki A, Abdel Hamid A, Hassan M and Abdel Kader H. Egypt Violence against Women study: Overview of services on violence against women. Combating Violence against Women Project. National Council for Women. April 2009. Retrieved on October 2012. Available at: http://www.usaid.gov.

14. Penhale B and Porritt J. Intimate partner violence against older women. National report United Kingdom. University of 
Sheffield, 2010. Retrieved on October 2013. Available at: https://www.uea.ac.uk.

15. Cress C. Handbook of geriatric care management. $2^{\text {nd }}$ ed., Jones and Bartlett publishers, 2007; 106-107.

16. Penhale B. In: Phelan A. (Ed.), International perspectives on older adult abuse. United Kingdom, London: Routledge, 2013: 188-205. Retrieved on January 2014. Available at: https://www.uea.ac.uk.

17. Anetzberger J. An update on the nature and scope of older adult abuse. Generations 2012; 36(3): 12-20. Retrieved on January 2014. Available at: https://www.asaging.org.

18. Nosheen H. Violence against women. The Dialogue 2011; 6(3): 290-299. Retrieved on December 2013. Available at: http:// www.qurtuba.edu.pk.

19. Centers for Disease Control and Prevention. Health-Related Quality of Life (HRQOL). 2011. Retrieved on March 2014. Available at: http://www.cdc.gov/hrqol/concept.htm.

20. Violence Prevention Initiative Women's Policy Office Government of Newfoundland and Labrador. Respect aging: An education and training program for recognizing, preventing and intervening in violence against older persons: Trainer's guide. 2013. Retrieved on January 2014. Available at: http://www.respectaging.ca.

21. World Health Organization. Violence against women: Intimate partner and sexual violence against women. Fact Sheet No. 239, 2014. Retrieved on November 2014. Available at: http://www.who.int.

22. Eliopoulos C. Gerontological nursing. $8^{\text {th }}$ ed., Philadelphia: Lippincott Williams \& Wilkins, 2014: 109-110.
23. Linton A and Lach H. Matteson \& McConnell's gerontological nursing: Concepts and practice. $3^{\text {rd }}$ ed., St. Louis: Saunders, an imprint of Elsevier Inc., 2007; 664 .

24. Briggs S. Domestic violence among older adults: A policy analysis of the violence against women acts of 2000 . Master Thesis of social work, school of social work: California University, 2012. Retrieved on January 2013. Available at: http://proquest.umi.com.

25. World Health Organization. WHO Violence against women instrument: A practical guide for researcher and activists. 2003. Retrieved on January 2012. Available at: http://www.path.org.

26. University of Washington. WHOQOLBREF. U.S. Version: United States of America, 1997. Retrieved on January 2012. Available at: http://dept.washington.edu.

27. Ahmed B. World health organization Quality of life (WHO QOL-BREF). 2008. Retrieved on January 2012. Available at: http://uqu.edu.sa.

28. Morsy N, Shalaby M and Abo-elyzeed S. Effect of partner abuse on the quality of life of married women. Life Science Journal 2013; 10(4): 2436-2445. Retrieved on March 2014. Available at: http://www.lifesciencesite.com.

29. Central Agency for Public Mobilization and Statistics Egypt. Violence against women in Egypt. United Nations Statistical Commission, 2009. Retrieved on March 2014. Available at: http://www.unstats.un.org.

30. Lazenbatt A, Devaney J \& Gildea A. Older women living and coping with domestic violence. Community practitioner 2013; 86(2): 28-32. Retrieved on March 2013. Available at: http://www.ncbi.nlm.nih.gov. 
31. Montero I, Martín-Baena D, EscribàAgüir V, Ruiz-Pérez I, Vives-Casese C and Talaveraf $M$. Intimate partner violence in older women in Spain: Prevalence, health consequences, and service utilization. Journal of Women \& Aging 2013; 25(4): 358-371. Retrieved on March 2014. Available at: http://www.ncbi.nlm.nih.gov.

32. Moraes S, Fonseca A, Bagnoli V, Junior J, Moraes E, Neves E, Rosa M, Portella $\mathrm{C}$ and Baracat E. Impact of domestic and sexual violence on women's health. Journal of Human Growth and Development 2012; 22(2): 253-258. Retrieved on March 2014. Available at: http://www.revistas.usp.br.

33. Wu L, Chen H, Hu Y, Xiang H, Yu X, Zhang $\mathrm{T}$, Cao $\mathrm{Z}$ and Wang $\mathrm{Y}$. Prevalence and associated factors of older adult mistreatment in a rural community in people's republic of China: A cross-sectional study. 2012. Retrieved on November 2013. Available at: http://www. journals.plos.org.

34. Ogrodnik L. Family violence in Canada: A statistical profile 2008. Ottawa, ON: Statistics Canada, 2008. Retrieved on October 2013. Available at: http://www.ywcacanada.ca.

35. Lazenbatt A, Devaney J and Gildea A. Older women's lifelong experience of domestic violence in Northern Ireland. Belfast, Northern Ireland: Queens
University Belfast. Mc Garry \& Simpson, 2011. Retrieved on March 2013. Available at: http://www.womensaidni.org.

36. Mc Garry J and Simpson C. Domestic abuse and older women: Exploring the opportunities for service development and care delivery. Journal of Adult Protection 2011; 13(6): 294-301. Retrieved on March 2013. Available at: http://www.emeraldinsight.com.

37. Hightower J, Smith J and Hightower C. Hearing the voices of older women. Journal of Gerontological Social Work 2006; 46(3/4): 205-227. Retrieved on October 2013. Available at: http://www.tandfonline.com.

38. Mudey A, Ambekar S, Goyal R, Agarekar S and Wagh V. Assessment of quality of life among rural and urban older adult population of Wardha district, Maharashtra, India. Ethno Med 2011; 5(2): 89-93. Retrieved on March 2014. Available at: http://www.krepublishers.com.

39. Wittenberg E, Joshi M, Thomas K and Mc Closkey L. Measuring the effect of intimate partner violence on health related quality of life: A qualitative focus group study. Health and Quality of Life Outcomes. License Bio Med Central ltd. 2007; 5: 67. Retrieved on November 2013. Available at: http://www.ncbi.nlm.nih.gov. 